\title{
KAJIAN SIFAT FISIKA TANAH DAS SUMPUR BAGIAN HULU KABUPATEN TANAH DATAR
}

\author{
Yulnafatmawita, Asmar, Aulia Rahman \\ Soil Scince Laboratory Andalas U niversity
}

\begin{abstract}
A research about study of soil physical properties in upper part of Sumpur Watershed in Tanah Datar Regency, West Sumatra was conducted in 2005. The objective of the research was to supply information about soil physical properties in the upper part of Sumpur watershed. These data are important to predict the erosion that can happen in that area and the impact to the surrounding area. Survey method with purposive random sampling was employed to this research for sampling soil in the field. Soil was sampled from each land use randomly. There were four types of land use found in the area, those were forest, mixed wood, annual season crops, and rice field. Based on field observation it was found that there were two classes of soils there, Andisols and Inceptisols. The results of laboratory analyses showed that soil texture in Andisols was silt loam, it was the same for each land use. Soil texture in Inceptisols, however, was finer than that in Andisols, it was clay. Bulk volume and total pores of both Andisol and Inceptisol for each land use were not yet different from those in the forest land use. Then, the value for plant available water, drainage pores, and water retaining pores in each land use for both soils were still comparable to those in forest and use. However, soil organic carbon (OC) content tended to decrease as land use change from forest to mixed wood, annual season crops, and rice field at both soils except for mixed wood land use in Inceptisol. The soil $\mathrm{OC}$ in that land use was slightly higer than that in the forest.
\end{abstract}

Key Words: Iand use, soil OC, soil physical properties

\section{PENDAHULUAN}

Daerah Aliran Sungai (DAS) sebagai suatu kawasan ekologi yang terdiri dari tanah, air, vegetasi dan hewan bermanfaat bagi manusia untuk pemenuhan kebutuhan dan peningkatan taraf hidupnya. Masing-masing faktor memiliki keterkaitan dan saling mempengaruhi. Bila manusia, yang berperan sebagai pengelola, tidak memperhatikan kaidah konservasi dalam mengusahakan suatu DAS maka akan timbul dampak negative terhadap faktor ekologi baik pada lingkungan itu sendiri maupun pada lingkungan perairan di bawahnya.

Daerah Aliran Sungai yang mempunyai kelerengan yang curam ( $>15 \%)$, seperti yang sering ditemui di daerah tropis basah khususnya di daerah Sumatra Barat, sangat peka terhadap erosi air. Hal ini sangat dirasakan bila daerah tersebut diusahakan untuk pertanian terutama tanaman semusim yang biasanya lahannya diolah secara intensif. Proses erosi oleh air ini akan mengikis tanah dari lahan pertanian dan mengalirkannya dipermukaan lalu mengendapkannya di bagian yang rendah, bahkan bisa lansung menuju sungai dan hanyut kebagian hilir. Hal ini bisa kita lihat dan buktikan yaitu dengan berubahnya debit dan warna air sungai saat atau beberapa waktu sesudah hujan. Bersamaan dengan hanyutnya tanah ini, unsur hara yang berada dalamnya juga ikut hilang ke bagian hilir. Dengan demikian kesuburan tanah akan menurun, terutama kesuburan fisika tanah.

Penurunan kesuburan fisika tanah akibat erosi sangat signifikan pada lahan pertanian yang diusahakan secara intensif, terutama pada pertanian tanaman semusim atau tanaman pangan. Pengolahan tanah yang intensif mengakibatkan aktifitas mikroorganisma meningkat karena terciptanya sirkulasi udara dan kelembaban yang menunjang kehidupannya. Mikroorganisma butuh bahan sebagai sumber makanan atau energinya, maka 
dengan demikian oksidasi bahan organic akan makin tinggi dengan pengolahan. Akibatnya, kandungan bahan organic tanah akan menurun dengan waktu, bila tidak ada penambahan secara regular. Sebagai salah satu indicator tingkat kualitas tanah, bahan organic mempengaruhi lansung atau tidak beberapa sifat fisika tanah, antara lain struktur, kandungan air, BV, TRP, konsistensi, stabilitas aggregate tanah dan lain sebagainya. Dengan menganalisis sifat fisika tanah bisa diprediksi tingkat degradasi lahan.

Daerah Aliran Sungai Sumpur merupakan salah satu DAS yang terdapat didaerah Sumpur Kecamatan Batipuh Kabupaten Tanah Datar yang merupakan bagian dari Daerah Tangkapan Air (DTA) Danau Singkarak. Daerah Tangkapan Air danau Singkarak sangat berperan dalam mendukung keberadaan sumber daya alam maupun sumber daya manusia yang berada disekitar kawasan tersebut. Oleh sebab itu, pengawetan DAS Sumpur ini sangat diperlukan demi kesinambungan perannya bagi kesejahteraan penduduk.

Akan tetapi, pada kenyataannya pengelolaan sumber daya alam pada DAS Sumpur ini tidak memperhatikan kaedahkaedah konservasi lahan. Pada DAS Sumpur bagian hulu yang seharusnya dijadikan sebagai kawasan konservasi sudah dijadikan lahan pertanian. Tambahan lagi, pengelolaan lahan yang dilaksanakan banyak menyalahi kaedah konservasi tanah dan air, diantaranya sawah pada daerah lereng terjal, ladang berpindah-pindah, dan pengolahan tanah yang tidak searah kontur. Hal tersebut telah menyebabkan perubahan beberapa sifat fisika tanah, yang bisa memicu timbulnya erosi di musim hujan.

Daerah aliran sungai (DAS) dengan semua factor pendukungnya merupakan suatu ekosistem yang sangat bermanfaat bagi kelansungan hidup manusia. Oleh sebab itu, DAS ini harus dilestarikan agar perannya dalam menunjang kehidupan manusia bisa berkesinambungan. DAS Sumpur bagian hulu sebagai salah satu bagian dari DTA Singkarak telah memperlihatkan adanya gejala peningkatan erosi akibat degradasi lahan oleh pembukaan hutan dan praktek pertanian yang tidak memperhatikan kaedah konservasi. Tingkat degradasi lahan yang terjadi bisa diprediksi dari sifat fisika tanahnya.

Berdasarkan beberapa keterangan diatas, maka dilakukan penelitian kajian sifat fisika tanah pada daerah bagian hulu DAS Sumpur. Tujuan dilakukanya penelitian ini adalah untuk memperkirakan tingkat penurunan kualitas tanah pada daerah hulu DAS Sumpur melalui pengukuran sifat fisika tanah.

\section{TINJ AUAN PUSTAKA}

Pengertian, Ciri dan Peran Daerah Aliran Sungai (DAS)

Daerah Aliran Sungai (DAS) adalah daerah yang dibatasi punggung-punggung gunung dimana air hujan yang jatuh pada daerah tersebut akan ditampung oleh punggung gunung tersebut dan dialirkan melalui sungai-sungai kecil ke sungai utama (Asdak, 1995). Dengan kata lain, DAS merupakan wilayah aliran air yang terbentuk secara alamiah dan secara fisik dibatasi oleh bentuk topografi. DAS juga dapat dipandang sebagai suatu ekosistem yang dinamis, karena unsur-unsurnya baik secara langsung maupun tidak langsung merupakan sumber daya alam yang dapat dimanfaatkan oleh manusia (Saidi, 1995).

Dalam mempelajari ekosistem DAS, daerah aliran sungai biasanya dibagi menjadi daerah hulu, tengah dan hilir. Daerah hulu DAS merupakan daerah konservasi, mempunyai kerapatan drainase lebih tinggi, kemiringan lereng besar (> 15 $\%$ ), bukan daerah banjir, dan pengaturan pemakaian air ditentukan oleh pola drainase. Sementara DAS bagian hilir merupakan daerah pemanfaatan, kerapatan drainase lebih kecil, daerah datar sampai kemiringan lereng sangat kecil $(<8 \%)$, pada beberapa tempat merupakan daerah banjir (genangan), pengaturan pemakaian air ditentukan oleh bangunan irigasi. Sedangkan DAS bagian tengah merupakan daerah transisi dari kedua DAS yang berbeda tersebut diatas (Asdak, 1995). 
Pengembangan DAS adalah rangkaian upaya yang dilakukan manusia untuk memanfaatkan sumber daya alamnya guna memenuhi kebutuhan dan meningkatkan taraf hidupnya. Sumber daya alam DAS terdiri dari unsure iklim, air, tanah, flora dan fauna, bahan mineral dan tambang yang baik berada diatas permukaannya maupun dibawah permukaan DAS tersebut (Sarief, 1985). Antara unsurunsur ini terjadi proses hubungan timbal balik dan saling mempengaruhi Unsur penyusun utama DAS seperti tanah, vegetasi dan air berperan sebagai objek atau sasaran fisik alamiah. Sedangkan manusia bertindak sebagai subjek pendayagunaan unsur-unsur tersebut. (Arsyad, 1989).

\section{Kerusakan DAS}

Kerusakan lahan erat kaitannya dengan peningkatan jumlah penduduk dalam suatu lingkungan daerah aliran sungai (Syarief, 1985). Atau dengan kata lain, jumlah penduduk suatu kawasan sudah melebihi daya dukung lahan (dinyatakan dengan jumlah penduduk yang dapat didukung kehidupannya per satuan luas lahan). Lingkungan yang ideal seharusnya seimbang antara lahan yang terbuka untuk diolah dan lahan yang masih terlindung secara alami, seperti hutan dengan vegetasinya yang lebat. Bila vegetasi berubah menjadi lahan perrtanian, baik lahan pertanian tanaman tahunan atau perkebunan apalagi tanaman bahan makanan semusim, mengakibat terjadinya peningkatan jumlah tanah tererosi, aliran permukaan ataupun muatan sedimen dari DAS tersebut. Hal utama yang menyebabkan perubahan itu adalah bila proporsi luas lahan pertanian lebih besar dari pada luas lahan hutan (Saidi, 1995).

Ada dua macam erosi yaitu erosi alamiah (erosi geologi) dan erosi dipercepat akibat aktivitas manusia. Erosi karena faktor alamiah umumnya masih memberikan media yang memadai untuk barlangsungnya pertumbuhan tanaman. Sedangkan erosi karena kegiatan manusia sudah membahayakan uasaha pertanian, karena kebanyakan berupa terkelupasnya lapisan tanah bagian atas akibat perbuatan manusia. Diantaranya tindakan manusia penyebab erosi yaitu cara bercocok tanam yang tidak mengindahkan kaidah-kaidah konservasi tanah atau kegiatan pembangunan yang bersifat merusak keadaan fisik tanah seperti pembuatan jalan di daerah dengan kemiringan lereng besar (Asdak, 1995).

Akibat yang ditimbulkan oleh erosi adalah (1) tubuh tanah menjadi tipis, tanaman tidak dapat tumbuh secara normal sehingga tanah menjadi tidak produktif karena lapisan atas sangat tipis, (2) Waduk, sungai, danau dan saluran irigasi didaerah hilir menjadi dangkal sehingga daya gunanya berkurang, (3) secara tidak langsung mengakibatkan banjir dimusim hujan dan kekeringan di musim kemarau (Seta, 1987).

Kerusakan yang paling nyata akibat erosi adalah terangkutnya lapisan olah tanah yang sangat penting artinya dalam budidaya pertanian, karena dalam lapisan tersebut tersedia dalam jumlah banyak unsur hara yang penting bagi tanaman, serta liat dan debu yang aktif dalam reaksi pertukaran kation dalam tanah (Hakim, Nyakpa, Lubis, Ghani, Diha, Hong dan Bailey, 1986).

Akibat erosi yang paling dirasakan didaerah tengah yang dilalui tanah tererosi dari lahan atas adalah terjadinya pengendapan pada sumber-sumber air, danau, dan bendungan-bendungan. Di daerah tengah ini terjadi pendangkalan waduk atau juga sungai-sungai sehingga sering terjadi banjir. Untuk daerah hilir, akibat erosi yang paling sering dan paling lama adalah banjir dengan segala konsekuensinya. Bila dibagian tengah hulu kekurangan air untuk kehidupan misalnya air minum dan pengairan, maka demikian pula halnya dengan daerah hilir yaitu semakin berkurangnya kualitas air minum (Rahim, 2000).

Bentuk wilayah atau topografi berperan dalam menentukan kecepatan aliran air di permukaan yang membawa partikel-partikel tanah tersebut. Sedangkan peranan vegetasi penutup tanah adalah melindungi tanah dari pukulan langsung tetesan air hujan dan memperbaiki struktur 
tanah melalui penyebaran akar-akarnya. Faktor kegiatan manusia memegang peranan yang sangat terutama dalam usaha-usaha pencegahan erosi, sebab manusia dapat memperlakukan faktor-faktor penyebab erosi lainnya, kecuali faktor iklim yang masih sulit diatasi (Sarief, 1985).

\section{METODA PENELITIAN}

Penelitian ini dilaksanakan dari bulan Mai sampai Oktober 2005 dilapangan (DAS Sumpur Bagian Hulu) dan dilaboratorium (Fakultas Pertanian Unand). Penelitian lapangan dilakukan dalam dua tahap, yaitu (1) tahap persiapan dan survey pendahuluan (2) serta survai utama untuk pengambilan contoh tanah.

Berdasarkan peta jenis tanah, DAS Sumpur bagian hulu ini yang terletak mempunyai 2 jenis tanah, yaitu Andisols dan Inceptisols. Sebagian lahan tersebut sudah dibuka oleh penduduk setempat untuk usaha pertanian. Beberapa penggunaan lahan yang terdapat disana yaitu di samping hutan ada sawah, tegalan, dan kebun campuran.

Penelitian laboratorium dilakukan di Laboratorium Jurusan Tanah Fakultas Pertanian Universitas Andalas. Bahanbahan dan alat-alat yang digunakan dalam penelitian ini dapat dilihat pada Lampiran 2.

Pada tahap persiapan ini dilakukan pengumpulan data sekunder mengenai lokasi yang akan dilakukan penelitian. Datadata tersebut meliputi: Peta jenis tanah, peta penggunaan tanah, peta topografi, dan peta titik-titik pengamatan. Survey pendahuluan dilakukan guna mengetahui keadaan lokasi penelitian dilapangan dan penetapan titik pengambilan sample tanah. Sampel tanah diambil dari setiap jenis tanah dan penggunaan lahan pada kelerengan yang seragam, yaitu $\pm 30 \%$.

Pengambilan contoh tanah dilakukan pada ke dua jenis tanah dan pada 3 tipe penggunaan lahan masing-masing jenis tanah. Ada 2 macam contoh tanah yang diambil, yaitu contoh tanah utuh dengan menggunakan ring sample untuk penetapan BV, TRP, energi potensial air tanah, serta contoh tanah terganggu untuk analisis distribusi ukuran partikel dan karbon organic (OC) tanah. Masing-masing contoh tanah diambil pada kedalaman 0-20 $\mathrm{cm}$.

Analisis tanah diantaranya: BV dan TRP dengan metoda Gravimetri, distribusi ukuran partikel tanah dengan metoda pipet dan ayakan (LPT, 1979), dan bahan organic tanah dengan metoda Walkley dan Black (Hakim et al, 1986). Analisis energi air tanah (PDL, \% PDC, \% PAT) dilakukan di laboratorium Fisika Tanah Universitas Jambi dengan menggunakan Pressure Plate Apparatus. Data yang diperoleh berupa sifat fisika tanah dinilai berdasarkan kriteria sifat fisika tanah.

\section{HASIL DAN PEMBAHASAN}

Dari Tabel 1 terlihat bahwa kedua jenis tanah yang ada pada Sub DAS Sumpur ini mempunyai tekstur yang berbeda pada kedalaman 0-20 cm. Andisols mempunyai tekstur yang lebih kasar. Prosentase pisahan tanah berukuran debu sedikit lebih besar dari berukuran liat, tetapi keduanya jauh lebih tinggi dari prosentase kandungan liat. Semua penggunaalan lahan pada tanah Andisols mempunyai tekstur yang tergolong pada kelas Lempung Berdebu. Hal ini sesuai dengan hasil penelitian sebelumnya bawa Andisols pada umumnya didominasi oleh partikel berukuran lebih kasar sehingga teksturnya pada umumnya termasuk lempung berdebu (Foss et al., 1983). Tanah bertekstur kasar ini mempunyai kapasitas infiltrasi yang besar, laju permeabilitas yang tinggi, serta kondisi aerase dan drainasenya bagus, sedangkan retensi airnya sangat tergantung pada kandungan bahan tanah. Sebetulnya jenis tanah ini bagus dijadilan lahan pertanian semusim, akan tetapi mempunyai kendala kelerengan yang agak curam (30\%). Oleh sebab itu, kalau memang harus dibuka untuk areal pertanian haruslah mengikuti kaidah konservasi dengan serius. Di samping itu, kandungan bahan tanah harus dipertahankan diatas rata-rata tanah mineral biasa untuk mempertahankan sifat fisika tanah yang baik.

Jenis tanah ke dua, Inceptisols, cendrung didominasi oleh pisahan tanah yang halus. Pada umumnya prosentase 
1. Distribusi Ukuran Partikel Pisahan Tanah dan tekstur Tanah

\begin{tabular}{llcccc}
\hline \multirow{2}{*}{$\begin{array}{l}\text { Jenis } \\
\text { Tanah }\end{array}$} & Penggunaan Lahan & \multicolumn{2}{c}{ Distribusi Partikel $(\%)$} & \multirow{2}{*}{ Tekstur } \\
\cline { 3 - 5 } & & Pasir & Debu & Liat & \\
\hline \multirow{2}{*}{ Andisols } & Hutan & 47.36 & 50.48 & 2.46 & Lempung Berdebu \\
& Kebun Campuran & 44.08 & 53.18 & 2.74 & Lempung Berdebu \\
& Tegalan & 24.09 & 72.09 & 3.82 & Lempung Berdebu \\
& Sawah & 47.86 & 50.97 & 1.17 & Lempung Berdebu \\
\hline \multirow{2}{*}{ Inceptisols } & Hutan & 11.01 & 35.32 & 53.67 & Liat \\
& Kebun Campuran & 14.19 & 37.73 & 48.08 & Liat Berdebu \\
& Tegalan & 14.74 & 42.75 & 42.51 & Liat \\
& Sawah & 12.30 & 37.56 & 50.14 & Liat \\
\hline
\end{tabular}

kandungan liat lebih tinggi dibanding prosentase debu dan liat. Berdasarkan segitiga tekstur USDA (Hillel, 1982) tanah ini bertekstur liat kecuali bagi lahan untuk tegalan. Berkurangnya kandungan liat pada penggunaan lahan tegalan ini mungkin disebabkan oleh proses pengolahan tanah untuk tanaman semusim di lahan ini. Pengolahan tanah telah meningkatkan oksidasi bahan, sehingga aggregat tanah menjadi mudah terdegradasi, dan bahkan sebagian terdispersi. Dengan adanya hujan, bagian tanah yang halus ini turun ke lapisan bawah atau dibawa aliran permukaan (runoff) ketempat lain atau tererosi. Berdasarkan tekstur tanah ini, maka tanahnya mampu meretensi air yang cukup, sirkulasi udara dan air yang baik. Akan tetapi ketersediaan air bagi tanaman sangat tergantung pada distribusi ukuran porinya. Secara umum, berdasarkan sifat fisikanya, tanah ini bagus dijadikan lahan pertanian, karena kandungan liatnya tidak terlalu tinggi yang akan menghambat proses pengolahan tanah. Namun, seperti tanah Andisols, kendala utama lahan ini untuk dibuka jadi areal pertanian adalah kelerengannya yang tinggi (30\%). Oleh sebab itu, sebaiknya dihutankan saja kalau tidak bisa mengikuti kaidah konservasi yang dibutuhkan untuk lahan ini.

\section{Karbon (OC) Tanah}

Kandungan karbon tanah pada setiap penggunaan lahan dari kedua ordo tanah diteampilkan pada Gambar 1.

Berdasarkan Gambar 1 terlihat bahwa kandungan karbon ke dua tanah tidak terlihat perbedaan yang menyolok. Berdasarkan kriteria sifat fisika/kimia tanah (LPT, 1979), kandungan karbon ke dua tanah termasuk pada kriteria sedang sampai tinggi. Hal ini mungkin disebabkan karena daerah ini baru dibuka, sehingga belum habis atau turun drastis dibanding hutannya.

Pada ordo tanah Andisol yang bertekstur lebihh kasar (Tabel 1) dibanding Inceptisols, kandungan karbon nya cendrung menurun dari tinggi (3.7\%) pada hutan menjadi sedang $(2.2 \%)$ pada lahan sawah. Hal ini disebabkan karena perubahan ekologi hutan menjadi lahan sawah telah 


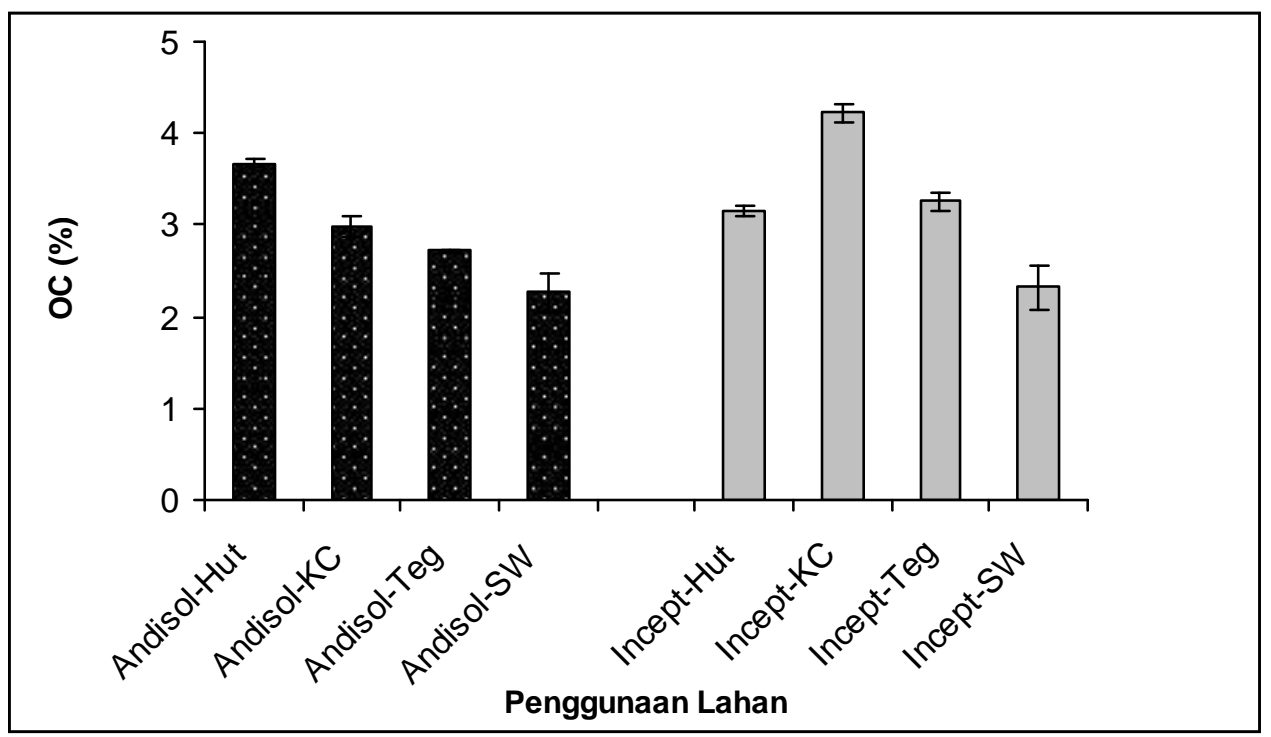

Gambar 1. Kandungan karbon (OC) setiap penggunaan lahan pada kedua ordo tanah di sub DAS Sumpur bagian hulu Kabupaten Tanah Datar

menghilangkan sumber bahan berupa vegetasi yang akan menyumbang karbon ke dalam tanah. Selanjutnya pengolahan tanah awal sebelum penggenangan sawah telah mengakibatkan teroksidasinya bahan tanah. Hal ini sesuai dengan apa yang didapatkan Yulnafatmawita (2006) bahwa perubahan penggunaan lahan dari vegetasi alami menjadi lahan sawah telah menurunkan kriteria kandungan karbon tanah pada lapisan 10-20 cm dari tinggi (3.9\%) menjadi sedang (2.3\%). Akan tetapi, walaupun kandungan karbon tanah berada dalam kriteria yang sama (tinggi) pada ekologi hutan, kebun campuran dan tegalan, perubahan penggunaan lahan dari hutan menjadi kebun campuran telah menurunkan OC tanah sebesar kurang lebih 19\%

dan menjadi tegalan sebesar $27 \%$. Rendahnya perubahan kandungan bahan tanah akibat pembukaan hutan ini mungkin disebabkan karena kegiatan pertanian ini belum berlansung lama. Jika kegiatan ini berlansung terus, maka bukan tidak mungkin kandungan OC tanah akan berada di bawah ambang kritis. Oleh sebab itu, perlu diantisipasi dari sekarang agar lahan tidak terdegradasi.

Pada tanah Inceptisol dengan tekstur halus kandungan karbon nya memperlihatkan kecendrungan yang agak berbeda dengan tanah Andisol. Lahan hutan mempunyai OC yang lebih rendah dari penggunaan lahan untuk kebun campuran (KC). Akan tetapi, kandungan $\mathrm{OC}$ menurun dari $\mathrm{KC}$ ke penggunaan lahan tegalan dan sawah. Rendahnya kandungan OC lahan hutan dibanding lahan untuk Kebun Campuran sangat mungkin sekali disebabkan oleh kondisi densitas tanaman pada masing-masing lahan. Kalau jumlah tanaman persatuan luas pada KC lebih besar dari hutan, dan perubahan lahan hutan menjadi KC ini sudah berlansung dalam waktu yang lama, maka jumlah input bahan yang jatuh di lahan $\mathrm{KC}$ lebih banyak dari di lahan hutan, sehingga kandungan OC lahan KC lebih tinggi dari lahan hutan. Apalagi hutan dewasa ini sudah lebih sering dijamah masyarakat setempat untuk mengambil kayunya, sementara KC yang sudah ada yang mengusahakan bisa terpelihara dengan baik tanpa ada gangguan.

\section{Berat volume Tanah}

Nilai kerapatan isi atau berat volume (BV) tanah dari kedua ordo tanah pada setiap penggunaan lahannya dapat dilihat pada Gambar 2. Terlihat perbedaan Bnilai BV tanah dari kedua ordo tanah. Tanah Andisol mempunyai nilai BV yang lebih rendah dari Inceptisol. Hal ini sesuai dengan salah satu syarat atau kriteria $g$ 


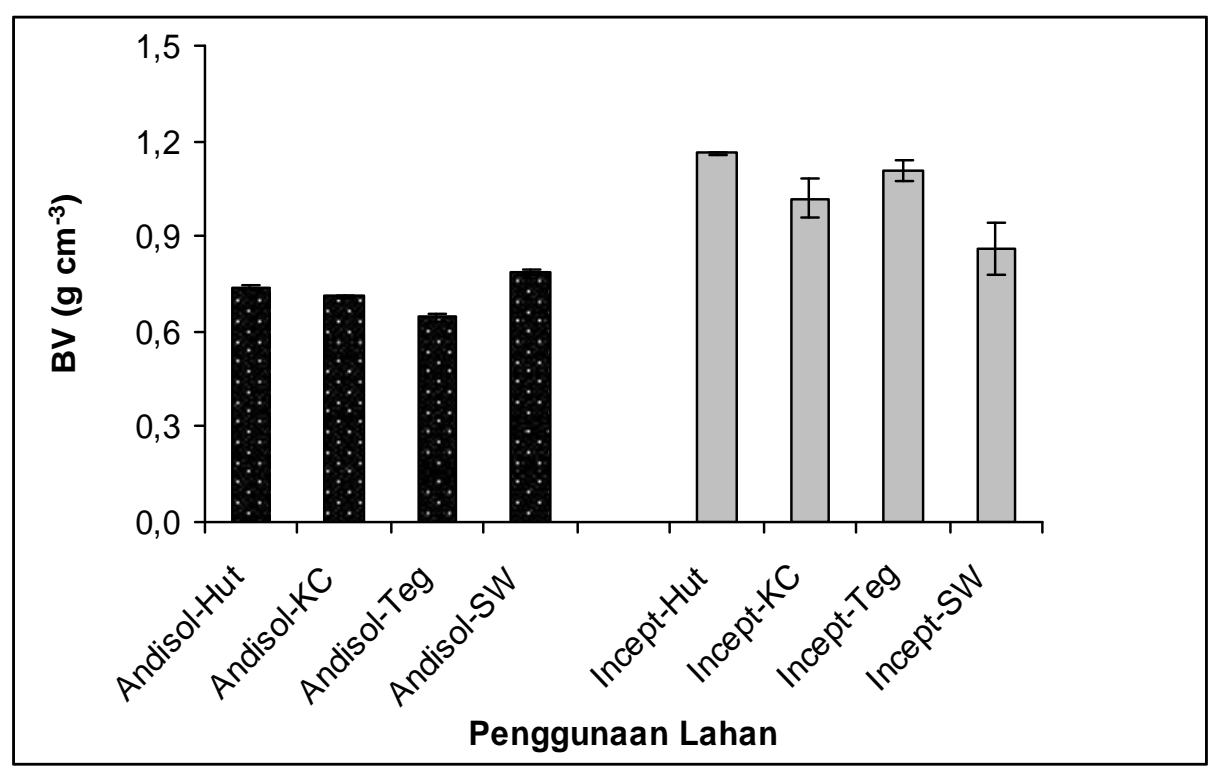

Gambar 2. Kerapatan isi (BV) setiap penggunaan lahan pada kedua ordo tanah di sub DAS Sumpur bagian hulu Kabupaten Tanah Datar

Andisol yaitu mempunyai BV rendah, $<0.85 \mathrm{~cm}^{-3}$ pada kondisi kapasitas lapang atau retensi air tanah pada tenaga $1 / 3$ atm (Foss et al., 1983). Sedangkan Inceptisol mempunyai BV umumnya $>1.0 \mathrm{~g}$ $\mathrm{cm}^{-3}$, kecuali lahan sawah.

Pada Gambar 2 terlihat bahwa BV tanah Andisol < $0.9 \mathrm{~g} \mathrm{~cm}-3$, atau berkisar dari $0.65-0.79 \mathrm{~g} \quad \mathrm{~cm}-3$ (Lampiran). Menurut Fiantis (2004) salah satu kriteria dari tanah Andisol yaitu mempunyai BV yang rendah, $\pm 0.8 \mathrm{~g} \mathrm{~cm}-3$. Jadi, nilai BV tanah Andisol masih berada dalam kriterianya. Hal ini berarti bahwa, perubahan penggunaan lahan dari ekologi hutan menjadi kebun campuran, tegalan dan sawah belum menyebabkan perubahan $\mathrm{BV}$ tanah Andisol dengan nyata. Walaupun BV tanah dengan penggunaan lahan untuk sawah memperlihatkan kecendrungan yang meningkat, tapi masih berada dalam kriteria sifat Andisol.

Tidak seperti Andisol, nilai BV Inceptisol pada lahan yang dipersawahkan cendrung menurun $(<1.0 \mathrm{~g} \mathrm{~cm}-3)$. Hal ini mungkin disebabkan oleh liatnya yang mempunyai kemampuan yang lebih tinggi untuk meretensi air pada kondisi titik layu atau kering-angin dibanding tanah bertekstur kasar. Dengan kata lain, tanah sawah yang diolah secara intensif, sampai dilumpurkan, akan mempunyai total ruang pori yang lebih tinggi dari penggunaan tanah lainnya, sehingga nilai BV nya menjadi lebih rendah.

\section{Total ruang Pori Tanah (\%)}

Total ruang pori ke dua ordo tanah ditampilkan dalam Gambar 3. Secara umum terlihat bahwa andisol mempunyai prosentase ruang pori yang lebih tinggi dari tanah Inceptisol. Nilai TRP berkaitan erat dengan nilai kerapatan isi suatu tanah. Semakin rendah nilai BV tanah, maka semakin tinggi jumlah ruang porinya (Hillel, 1982). Secara umum, nilai BV Andisol lebih rendah dari Inceptisol pada setiap penggunaan lahan (Lampiran), oleh sebab itu nilai prosentase ruang porinya menjadi lebih tinggi dari Inceptisol.

Prosentase total ruang pori Andisol berkisar dari 70-75\%, menurut LPT (1979), kondisi ini termasuk pada kriteria sedang. Belum terlihat perubahan kriteria TRP tanah pada Andisol akibat alih fungsi lahan hutan menjadi kebun campuran, tegalan, maupun sawah. Selama nilai BV suatu tanah mineral, di samping dipengaruhoi oleh kandungan BO tanah, hanya ditentukan oleh BV tanahnya, maka nilai prosentase ruang pori tanah dipengaruhi oleh faktor yang mempengaruhi BV tanah tersebut. Hubungan antara nilai BV dan TRP tanah 
Andisol dan Inceptisol Sub DAS Sumpur bagian hulu dapat dilihat pada Gambar 4. Sekitar $84 \%$ nilai TRP tanah dipengaruhi oleh nilai BV nya.

Hal yang sama juga dijumpai pada Inceptisol, dimana nilai prosentase total ruang pori masing-masing penggunaan lahan berbanding terbalik dengan nilai $\mathrm{BV}$ nya. Lahan hutan yang mempunyai nilai BV paling tinggi mempunyai prosentase ruang pori paling rendah, tetapi masih dalam kriteria sedang (LPT, 1979). Berdasarkan kenyataan tersebut, seolah-olah pembukaan lahan hutan belum mempengaruhi kondisi ruang pori tanah. Akan tetapi, nilai TRP belum menjamin bagusnya kondisi aerase dan drainase tanah. Kondisi sirkulasi udara dan air di dalam tanah, serta banyaknya air yang bisa tersedia bagi pertumbuhan tanaman hanya ditentukan oleh distribusi ukuran pori tanah yang diukur melalui energi potensial air tanah.

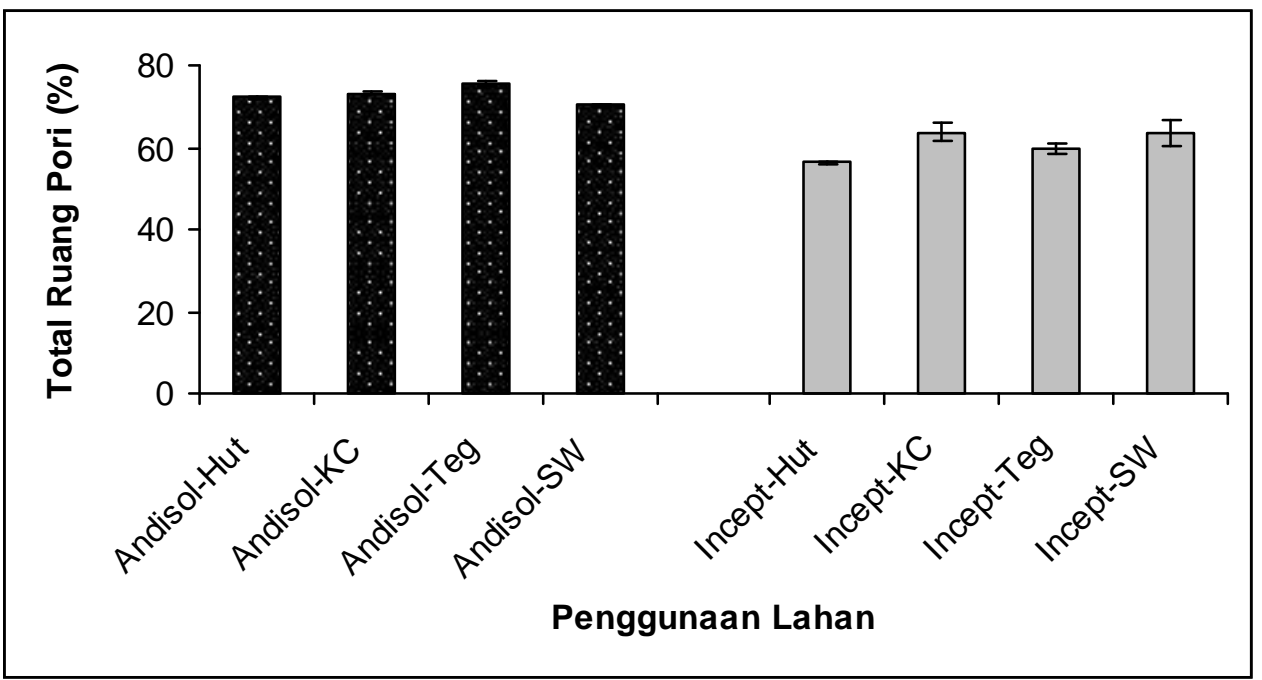

Gambar 3. Nilai total ruang pori (TRP) setiap penggunaan lahan pada kedua ordo tanah di sub DAS Sumpur bagian hulu Kabupaten Tanah Datar

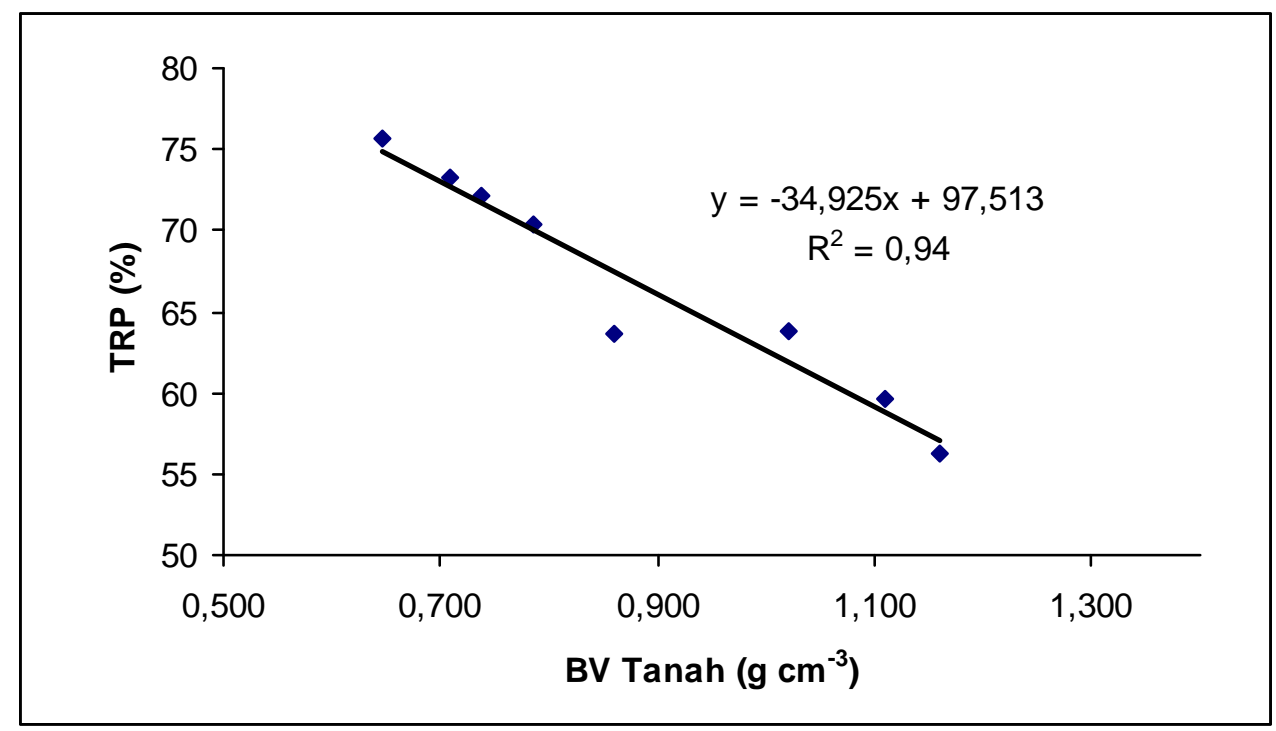

Gambar 4. Hubungan antara BV dan TRP pada dua ordo tanah di sub DAS Sumpur bagian hulu Kabupaten Tanah Datar 


\section{Energi Potensial Air Tanah}

Dari hasil analisis energi potensial air tanah didapatkan 3 klas distribusi pori, diantaranya pori air tersedia (Gambar 5), pori drainase cepat atau pori aerase (Gambar 6), serta pori drainase lambat (Gambar 7).

Pori air tersedia (Gambar 5) yaitu pori tanah yang menahan air antara $1 / 3-15$ atm atau pori kapiler yang berukuran antara
8.6 - 2 um (Supardi, 1975). Secara umum, pori air tersedia Andisol lebih tinggi dari Inceptisol. Hal ini mungkin disebabkan oleh perbedaan tekstur dari kedua tanah. Tanah yang bertekstur lempung akan mempunyai jumlah air tersedianya lebih tinggi dari tanah bertekstur pasir ataupun liat (Hillel, 1982, Supardi, 1975, Syarief, 1986).

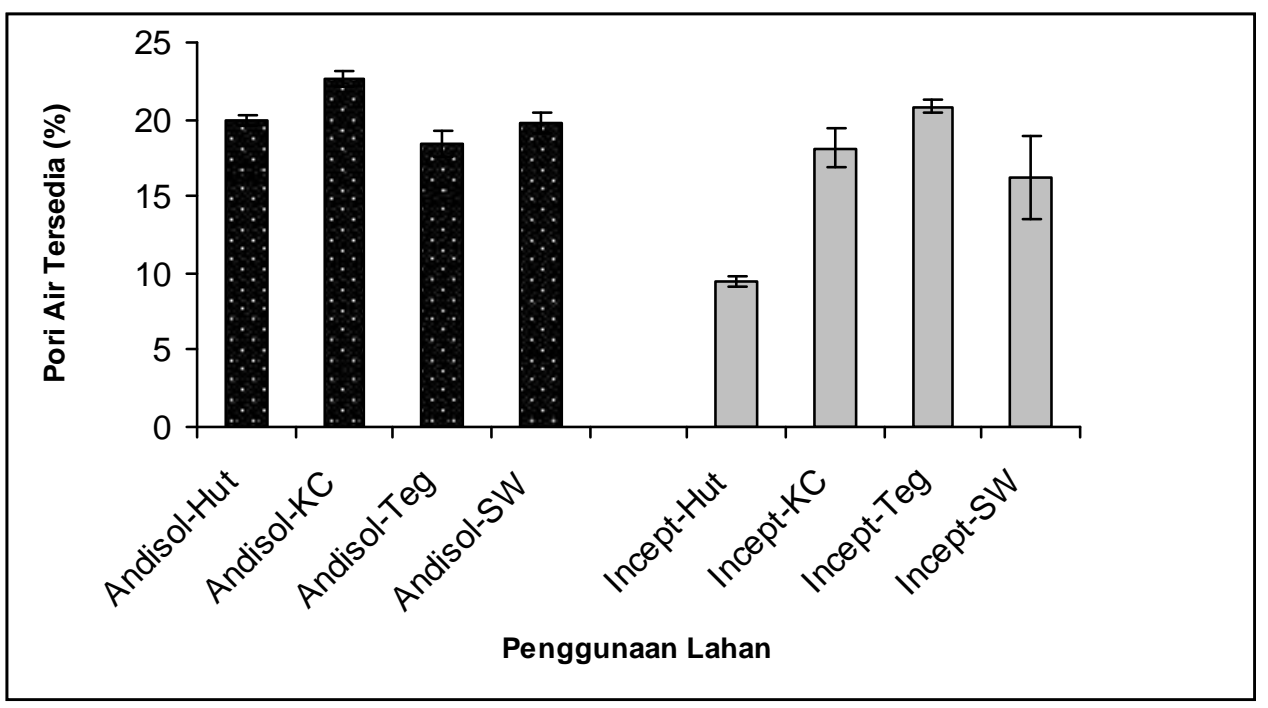

Gambar 5. Nilai pori air tersedia (PAT) setiap penggunaan lahan pada kedua ordo tanah di sub DAS Sumpur bagian hulu Kabupaten Tanah Datar

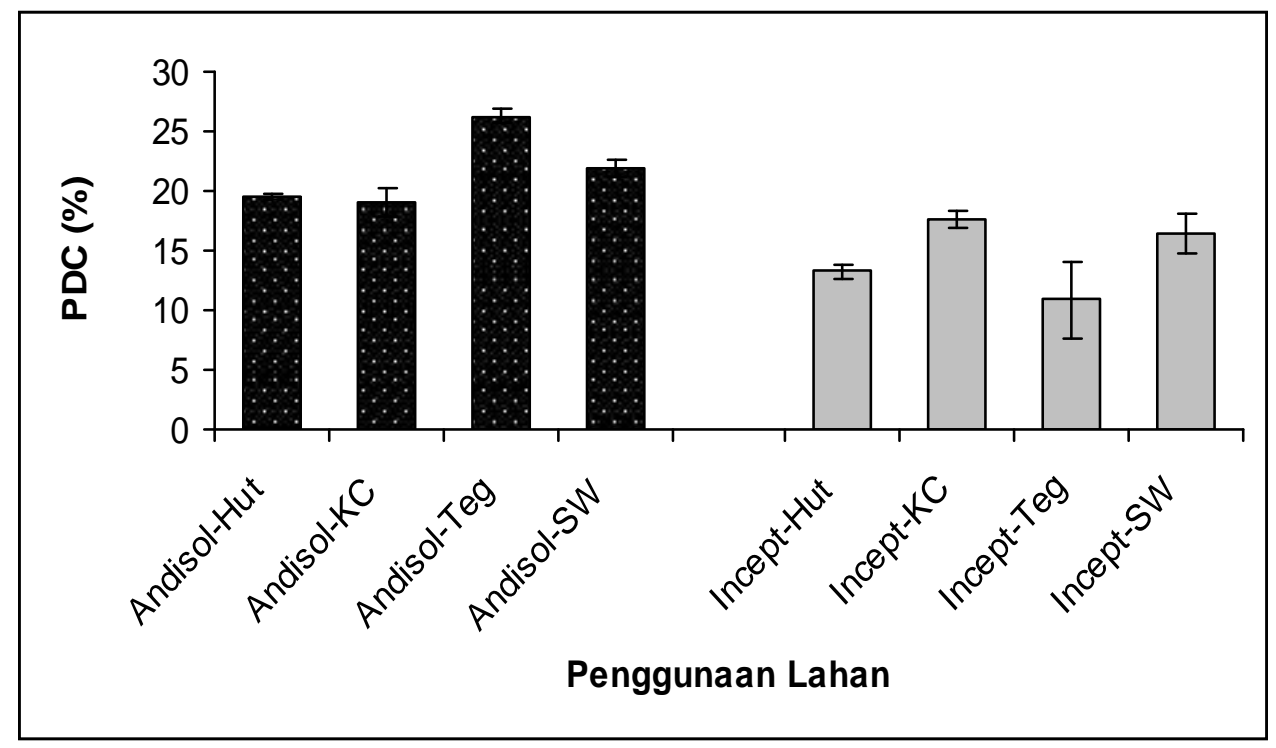

Gambar 6. Nilai pori drainase cepat (PDC) setiap penggunaan lahan pada kedua ordo tanah di sub DAS Sumpur bagian hulu Kabupaten Tanah Datar 


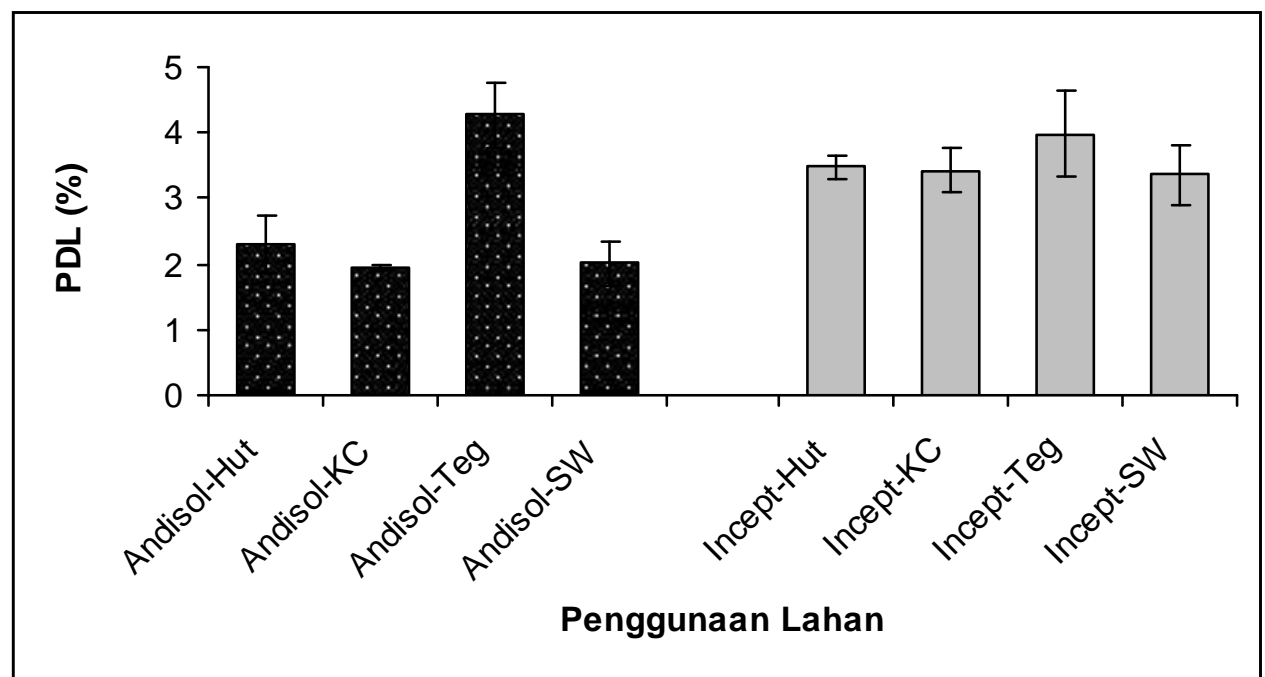

Gambar 7. Nilai pori drainase lambat (PDL) setiap penggunaan lahan pada kedua ordo tanah di sub DAS Sumpur bagian hulu Kabupaten Tanah Datar

Dari ke empat penggunaan lahan pada Andisol, jumlah air tersedianya bagi pertumbuhan tanaman berkisar dari kriteria tinggi (HU, TEG, SW) dan sangat tinggi (KC) menurut LPT (1979). Selanjutnya, pori drainase cepat (Gambar 6) Andisol pada semua penggunaan lahan termasuk kriteria tinggi yaitu > 15\% (LPT, 1979). Tingginya \% PDC Andisol berkaitan erat dengan jumlah praksi kasar dari tekstur tanahnya (Tabel 1). Semakin banyak jumlah partikel kasar ( pasir dan debu) pada suatu tanah maka semakin banyak jumlah pori makronya. Selanjutnya, semakin sedikit fraksi halus, maka semakin kecil jumlah pori drainase lambatnya. Berdasarkan Tabel 1, Andisol mempunyai kandungan liat yang sangat rendah $(<5 \%)$, maka prosentase pori drainase lambat (Gambar 7) tanah ini termasuk kriteria sangat rendah (LPT, 1979).

Sedikit berbeda dari Andisol, jumlah air tersedia tanah Inceptisol pada lahan hutan jauh lebih rendah dari lahan lainnya. Menurut LPT (1979), prosentase pori air tersedia lahan hutan termasuk kriteria rendah, kebun campuran dan sawah termasuk tinggi, sedangkan tegalan termasuk sangat tinggi. Selanjutnya, prosentase pori drainase cepat (PDC) atau pori makro tanah termasuk kriteria rendah (TEG), sedang (HU), dan tinggi (KC dan SW). Akan tetapi, seperti Andisol, jumlah pori drainase lambatnya termasuk kriteria sangat rendah, kecuali pada penggunaan lahan tegalan termasuk rendah.

\section{KESIMPULAN}

Dari hasil analisis laboratorium terhadap beberapa sifat fisika tanah sub DAS Sumpur Bagian Hulu dapat disimpulkan bahwa alih fungsi lahan dari ekologi hutan menjadi kebun campuran, tegalan, dan sawah secara umum belum menurunkan kondisi fisika tanah, kecuali kandungan OC tanah. Hal ini terbukti bahwa:

1. Tekstur tanah pada Andisol antara lahan hutan dengan lainnya masih sama, yaitu lempung berdebu. Demikian juga dengan tanah Inceptisol, belum terjadi perubahan tekstur kecuali pada lahan Tegalan yang telah mengalami penurunan kandungan liat

2. Nilai BV dan TRP bagi kedua tanah untuk setiap penggunaan lahan belum berubah dari lahan hutan

3. Nilai \%PAT, \%PDC, dan \%PDL masing-masing tanah pada setiap penggunaan lahan tidak lebih jelek dari kondisi lahan hutannya

4. Ada penurunan kandungan OC tanah pada Andisol dengan perubahan ekologi hutan menjadi kebun campuran, tegalan dan sawah. 
Akan tetapi, pada Inceptisol, terlihat peningkatan OC tanah dari hutan menjadi kebun campuran. Kemudian dari kebun campuran menjadi lahan tegalan dan sawah menurunkan OC tanah.

Saran

Dengan terlihatnya ada kecendrungan kandungan OC tanah, yang merupakan kunci penentu sifat fisika tanah bahkan kesuburan tanah mineral, maka pembukaan lahan yang lebih lanjut harus diantisipasi agar tidak terjadi degradasi lahan. Tindakan konservasi daerah ini penting sekali dilakukan mengingat daerah penelitian merupakan hulu dari sub DAS Sumpur yang merupakan daerah tangkapan air (DTA) danau Singkarak.

\section{DAFTAR PUSTAKA}

Arsyad, S. 1976. Pengawetan Tanah dan Air. Departemen Ilmu Tanah Fakultas Pertanian IPB. Bogor.

Arsyad, S. 1982. Konservasi Tanah dan Air. Departemen Ilmu-Ilmu Tanah Pertanian IPB. Bogor..

Arsyad, S. 1989. Pengawetan Tanah dan Air. Departemen Ilmu Tanah Fakultas Pertanian IPB. Bogor.

Asdak, C. 1995. Hidrologi Dan Daerah Aliran Sungai. Gadjah Mada University Press. Yogyakarta.

Foss, J.E., Moormann, F.R., and Rieger, S. 1983. Inceptisols. Dalam "Pedogenesis and Soil Taxonomy II. The Soil Orders" edited by L.P. Wilding, N.E. Smeck, and G.F. Hall). Developments in Soil Science 11B.Elsevier, Amsterdam. 355-382 pp.
Hakim, Nurhayati, M.Y. Nyakpa, A.M Lubis, S.G. Nugroho, M.R. Saul, M.A. Diha, G.B. Hong, dan H.H. Bailey. 1986. Dasar-Dasar IImu Tanah. Universitas Lampung.

Hilmar, F.D. 1991. Prediksi Erosi Dan Penilaian Besarnya Sedimentasi Daerah Aliran Sungai Kuranji Bagian Hulu Kodya Padang. Skripsi Fakultas Pertanian Universitas Andalas. Padang

Rahim, S.E. 2000. Pengendalian Erosi Tanah Dalam Rangka Pelestarian Lingkungan Hidup. Bumi Aksara. Jakarta.

Rusman, B. 1999. Konservasi Tanah dan Air. Fakultas Pertanian Universitas Andalas. Padang.

Saidi, A. 1995. Aliran Permukaan, Sedimentasi Serta Faktor-Faktor Yang Mempengaruhinya Serta Dampaknya Terhadap Degradasi Lahan Di Sub DAS Sumani Solok Sumatera Barat. Disertasi Pasca Sarjana Unpad. Bandung.

Seta, A. K. 1987. Konservasi Sumberdaya Tanah dan Air. Kalam Mulia. Jakarta.

Suwardjo, H. 1986. Pengaruh panjang lereng dan cara pengelolaan lahan terhadap erosi dan pertumbuhan kedelai. Press Pen Tanah No 6. PPT Bogor.

Syarief, E.S. 1985. Konservasi Tanah dan Air. Pustaka Buana.

Yulnafatmawita. 2006. Hubungan antara status C - dan stabilitas aggregat tanah Limau M anis Padang akibat perubahan penggunaan lahan. Prosiding "Seminar Tahunan Dosen BKS-PTN Barat" 25-27 April 2006 di Jambi. 